\title{
One Text, Multi-Tasks Meeting the Mixed-Ability Challenge
}

\author{
Dulip Singh a/l Ranjet Singh (Corresponding author) \\ KAMPUS TUN ABDUL RAZAK \\ E-mail: dulipsingh@ipgmktar.edu.my
}

Doi:10.7575/aiac.alls.v.4n.1p.1

URL: http://dx.doi.org/10.7575/aiac.alls.v.4n.1p.1
Received: 01/12/2012

Accepted: 05/01/2013

\begin{abstract}
It is a fact that each individual is unique. This uniqueness can be physical, emotional, intellectual and/or spiritual. It follows then that in any given learning environment each learner has unique abilities and needs. Consequently, classrooms everywhere, even if they are streamed, are of a mixed-ability nature. Having recognised this factor in learning, the KSSR (Kurikulum Standard Sekolah Rendah) emphasises learner-centredness. It is a daunting responsibility for a beginning English Language (EL) teacher faced with the task to cater to these varied learning abilities. The ELT (English Language Teaching) fraternity recognises this learning ability and has categorised learners as HEP (High English Proficiency), SEP (Some English Proficiency) and LEP (Low English Proficiency) learners. This 'One text, multi tasking' technique of materials development could help a beginning or even a dedicated EL teacher deal with these individual learning styles while fulfilling many components of the Malaysian pedagogy standards for ELT.
\end{abstract}

Keywords: one text, multi-tasks, ELT

\section{Introduction}

The Textbook Loan Scheme or Skim Pinjaman Buku Teks (SPBT) has been in place since 1975 (BBT, KPM: 2010). I used them as a student. I found answers written in most of them. I did not have to think for answers, thanks to my seniors. Although, we were reminded by our teachers not to write in them, I remember defying the reminders.

As a teacher, I rediscovered SPBT textbooks with answers written in them for my students by their seniors. They were regurgitating answers in a similar way which was familiar to me. I wondered if I was producing thinking students. I began to consider the SPBT scheme a deterrent to the critical and creative thinking skills.

\section{Background of the innovation}

For my final academic submission, I identified addressing the mixed-ability nature of Malaysian EL classrooms as the topic for my dissertation. I considered McEldowney's (1992) Communicative Purposes Language Learning Cycle (CPLLC) grammatical framework as a probable solution. The CPLLC grammatical framework enables the teacher to plan his/her teaching after the communicative purpose(s) of a text has been determined.

McEldowney (ibid: 45) says that we should consider the three main communicative purposes in a language teaching and learning pedagogy. These communicative purposes are instructions, descriptions and narrations. Figure 1 below encapsulates McEldowney's CPLLC grammatical framework for pedagogical grammar.



Figure 1. McEldowney’s CPLLC Grammatical Framework

According to her (ibid: 46), the communicative purpose of a text and/or discourse is marked by "clusters of appropriate grammatical markers". These markers are verbs and the forms they take. To help identify these purposes, let us look at these three texts: 
Text 1: Lightly smack each orange on the counter. Cut each one in half. Squeeze into a glass. You may also use a citrus reamer to do this. If you want less pulp, use a hand juicer with a strainer.

- $\quad$ http://allrecipes.com/recipe/fresh-orange-juice/detail.aspx

Text 2: The reason why oranges are green in a tropical climate is because the weather rarely gets cold. Because of the lack of cool weather, the chlorophyll remains in the skin of the orange, keeping it green. When an orange is exposed to cool weather while still on the branch, it turns to orange.

- http://www.omg-facts.com/Science/Oranges-Are-Green-Not-Orange-WhenGrown/52278\#RWgf8XIH3hjYzVAx.99

Text 3: Niyot came home from work. She needed a cold drink. She went to the fridge and opened it. She took out a packet of orange juice and poured some into a glass. She took a sip but it tasted awful.

- Scripted

The topic of the three texts above revolves around oranges. All the main verbs in the three texts are in bold. The forms the verbs take in the text are in the stem, stem $+s$ and stem $+e d$. Stem, according to the Oxford Dictionary of English Grammar (1994: 372-373) is "an element in word formation". The dictionary elaborates that "for some linguists stem is the primitive unit of morphology ... and in historical linguistics, the stem is the part of the word to which inflectional endings are attached". In this case, the ' $+\mathrm{s}$ ' and 'ed' are examples of inflections. This definition of stem will be used in this discussion, that is, the stem is the part of the word to which inflectional endings are attached.

The verb in its stem form or "the imperative" is often used for the purpose of giving instructions as in Text 1 above. This purpose is marked by the verbs smack, cut, squeeze, use, and use. These verbs refer to actions and McEldowney (1992: 13) calls them 'dynamic' or 'action verbs'. Most D-I-Y instructions, recipes and manuals exhibit this verb form. They are also common for giving directions.

The verb in its $s t e m+s$ form, or "the simple present", is commonly used for the purpose of describing as is evident in Text 2. This purpose is signalled by the verbs are, is, gets, remains, and turns. The verbs are, is and remains do not refer to actions. Instead, they express a state of being and McEldowney (ibid) calls them 'static' or 'stative' verbs. Similarly, Tomasello (1992: 13) classifies two types of verb-event concepts. They are the change of state and action. He (ibid) states that "change of state concepts concern those processes in which the defining feature is something relatively abstract happening to an experiential entity. On the other hand, "action concepts concern those processes defined by the actual behaviors of the animate or inanimate being" opines Tomasello (1992: 13). This can be seen in Text 2 where the verbs are, is and remains are state concepts while the verb gets and turns are action concepts.

Finally, the verb in its stem $+e d$ form, or "the simple past", is widely used in narrating incidents as represented in Text 3. The verbs came, needed, went, opened, took, poured, took and tasted signal this purpose. The stem of these verbs take on inflections as in needed and tasted for their regular forms or the "inflection" is graphemic and vocal as in come to came and go to went and read/ri:d/ to read/red/for their irregular forms. McEldowney (ibid: 45) says that these forms account for at least three-quarter or 75 percent of all verb form usage in the English language.

However, discourses in the English language in actuality do not occur as distinctly as the texts above. McEldowney says that communicative discourses will contain embedding of two or more of these purposes. To recognise this type of text, let us look at the text below:

Simran felt unwell. So, he went to see a doctor. The doctor advised him to take more vitamins. He said, "Oranges are good. They contain lots of Vitamin C. Buy those that are big and juices." Simran came home with some oranges. He did not know how to make orange juice. His brother, Roshan, said to him: Cut an orange into halves. Then, squeeze it on a squeezer. Next, pour the juice into a glass. After that, add some sugar and ice-cubes. Finally, stir it before drinking.

There are two types of verbs in the discourse above; the finite and non-finite verbs. (The finite verbs are in bold while the non-finite verbs are underscored.) Texts with embedded verb forms, thus embedded communicative purposes, are a reflection of authentic language discourse. A language teacher should use such texts as input materials. Learners should be exposed to such authentic materials for they represent materials that learners will encounter outside the school time.

This awareness should be the take off point for the organisation of English language learning materials. Therefore, for pedagogical purposes the EL teacher should structure his/her lesson around the communicative purpose s/he is required to teach. This procedure gives the teacher some form of focus for the lesson besides highlighting the grammatical item that is crucial for effective communication. In relation to this point Nunan (1999: 76-77) opines that such procedures "allow learners to practice identifying the key grammar and vocabulary in real-world texts and to develop the skills of reading, writing, speaking and listening in an integrated way, just as in authentic communicative situations" outside the classroom. The classroom functions as a bridge to the outside world and not as "a linguistic quarantine station where learners are protected from the risks involved in having to engage in genuine communication" (Nunan: ibid).

The pedagogic principles of the CPLLC grammatical framework proposed by McEldowney has many similar features of second language teaching techniques and principles currently practised in ELT classrooms in many countries. Yet, 
this grammatical framework is different for teaching English as compared to existing materials presented in many Malaysian ELT textbooks (See Appendix 1 and 2).

\section{Producing these task sheets}

To produce mixed-ability tasks using this framework, first, study the material provided in the textbook. Next, identify its main communicative purpose. For example, the material by Ab. Majid (2006) asks the reader "Do you know how paddy is grown?" in Activity 2 entitled Let's talk. This clearly signals a description of a process as its communicative purpose. The verb phrase 'is grown' in the stem + stem $+e d$ structure is the passive form. McEldowney's CPLLC grammatical framework classifies this structure as a description of a man-controlled process (See Figure 1 above). The text below exemplifies this purpose.

Once the fruit is picked, oranges are hand graded and any fruit that doesn't meet quality inspections is removed. The oranges are then washed and the orange oil is extracted from the peel to capture the from-theorange taste, which is later blended into the juice for consistent quality and flavor. The oranges are squeezed and the fresh juice is flash pasteurized.

\section{- http://en.wikipedia.org/wiki/Tropicana_Orange Juice}

Returning to task of recognising the communicative purpose, a closer scrutiny of Ab. Majid's text reveals that paragraph 2 to paragraph 4 describes the process of paddy growing and rice producing. However, the process is made difficult by mixing the active as well as passive sentences. This is where the EL teacher's grammatical awareness is crucial. Widdowson (2008) believes that the EL teacher must not only be grammatically competent but also see the "principled connection" between usage and use to enable him/her to modify or simplify the material. He (ibid, 145) opines that "any informed pedagogic practice should re-align existing ideas and practices so that they are more effective."

Continuing the process of effective materials production, once the communicative purpose of the text has been determined, a suitable graphic organiser (GO) should be identified as a scaffold for core notes production (See Appendix 3). Paddy growing and rice producing is a process. Therefore, a flow or sequence-chart is suitable. Each communicative purpose can be represented through a basic GO. The teacher has to identify them. The I-Think Maps recently introduced into the Malaysian education system may come in handy here.

Once a GO has been identified, study the material and make core notes by locating the information required. In the sample (Appendix 3) Row 1 of the core notes sign-posts the peripheral information required to complete the process. This information is guided by WH-questions which are commonly used in brainstorming a topic for study. This acts as an information-gap activity giving the learners a purpose for reading or listening. It is now important to control the grammatical structure to be introduced in the lesson. Going back to the material by Ab. Majid (2006), the process of growing paddy and producing rice is presented in active sentences except for one sentence in paragraph 4 'At the rice mill the harvested paddy is processed into white rice.' This is a passive sentence marked by the verb form - stem + stem+ed. ELT practitioners say that learners notice patterns and form hypotheses about the language structure. A change in the sentence structure might debilitate noticing. Therefore, the teacher has to modify the input to reflect regular patterning. This decision lies with the teacher and his/her scheme of work.

Being aware that paddy growing and rice producing is a human activity; I decided to change all the sentences into the passive. Thus, sentence 1 in paragraph 2 'The farmers use tractors to level and plough the land' is changed to 'Tractors are used by farmers to level and plough the land'. In view of this, McEldowney (1992) distinguishes the communicative purpose of description to being static or dynamic as well as man-controlled (to be politically correct, I shall use the term "human-controlled) or nature-controlled. The text below exemplifies a description of a naturecontrolled process.

So, what causes oranges on orange trees to split? The rind splits because water and plant sugars travel to the fruit too quickly for it to produce enough rind to hold the substances. The excess fluids cause the skin to burst. Young trees have the highest incidence of oranges splitting. Most cases of splitting citrus fruit occur in July to November.

- http://www.gardeningknowhow.com/edible/ fruits/oranges/ oranges-splitting.htm

Having completed the GO and the core notes, they then become the basis of mixed-ability task development. The teaching and learning context is central in deciding the enhancement or simplification of the tasks. The HEP learners (See Appendix 4) can handle enhanced tasks while the LEP learners (See Appendix 5) might need a simplified version of the task. The SEP learners (See Appendix 6) will have a task which falls between the HEP and LEP tasks. The amount of freedom or assistance rendered is determined by the teacher who knows his/her learners best. Figure 2 below attempts to capture the process of producing materials that meet the challenge of the mixed-ability nature of our classrooms. 


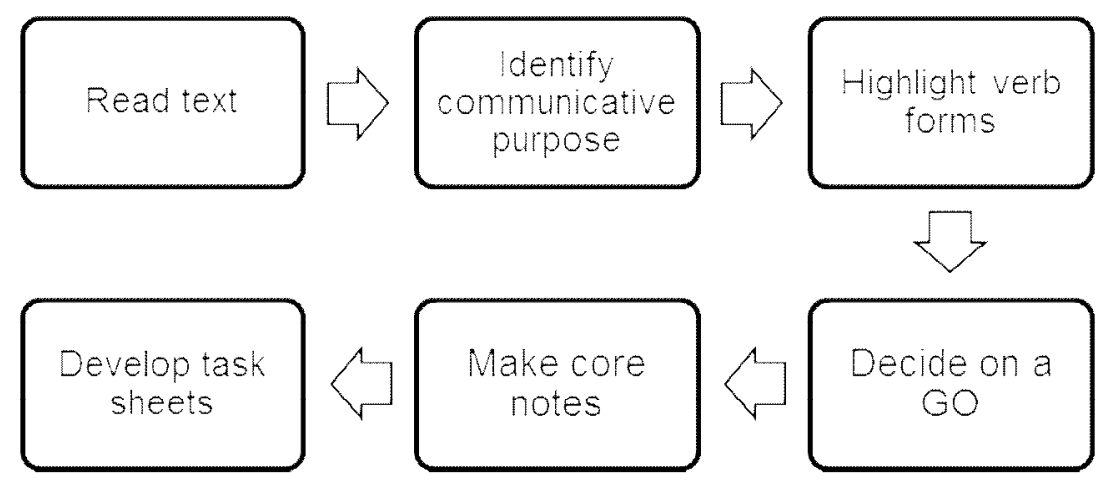

Figure 2. The process of producing 3Tasks from 1Text

\section{The advantage of this procedure}

Producing tasks using the CPLLC grammatical framework adds mileage to their use. They can be exploited at the postreceptive (listening or reading) skill stage of the lesson. For instance, having gathered the information during the whilelistening or while-reading stage, the language content can be addressed. Once again this decision lies with the teacher and his/her scheme of work. Assuming that listening and speaking are the focus skills of the lesson; the learners would listening to an input (discourse) and complete the GO at the while-listening stage. In the post-listening stage of the lesson, the GO becomes the springboard to comprehension questions, pronunciation exercises, grammar exercises related to the sound system as well as vocabulary exercises. Many EL teachers may not be aware that grammar is present in vocabulary and pronunciation too.

Since the listening and speaking skills go together, a must post-listening activity would be speaking. Learners in an ESL/EFL (English as a Second Language/English as a Foreign Language) environment need some form of support to help them succeed in producing the language. The GO from the while-listening stage can act as a springboard to speaking activities. A scaffolding activity comes to mind where the teacher or even proficient learners can help the less proficient ones to produce language orally.

The same procedure applies to the literary skills of reading and writing. In this paper, it is suggested that the postreading skill is writing a summary of the paddy growing and rice producing process (See Activity 2 of Appendix 4, 5 and 6). Having gathered the information required by the task, the teacher gets the learners to write a summary of the topic, that is, paddy growing and rice producing. Prior to writing, the teacher could work on the grammar in focus as well as punctuation. (Notice that the notes are in lowercase.) This activity replicates real life language function for academic purpose where one reads a reference book, takes specific notes and eventually uses this information for a writing project. This technique helps the learners paraphrase. Indirectly, the learner is avoiding plagiarism, an academic skill lacking in many learners even at institutions of higher education.

\section{The implementation of the innovation}

I used similar task sheets with the TESL January 2011 intake student teachers when teaching them TSL 3105 Teaching Listening and Speaking in the Primary ESL Classroom, TSL3108 Teaching of Grammar in the Primary ESL Classroom and also TSL3110 Linking Theory to Practice for three semesters. I introduced these materials in Semester 3 during the TSL3105 classes. I used these materials again in Semester 4 during the TSL3108 classes. In Semester V during the TSL3110 subject, I introduced this procedure of material development to these student teachers. I justified that they would be meeting the mixed-ability challenge through this procedure.

During a Staff Development Training session (LPS) for the lecturers from the English Language department, I enquired about the use of these types of tasks among their supervisees during the Phase 1 of Practicum. The supervisors informed me that no such task sheets were evidently used by their supervisees. (Or maybe the supervisors were unaware of this procedure and did not pay particular attention to the task-sheets.) It can also be interpreted as since this technique of material development is outside their Course Pro Forma, the student teachers did not consider it as an effective procedure.

However, a few colleagues agree that they find these task sheets useful. They suggested that the procedure in producing the task sheets be introduced to the student teachers. These student teachers need to be made aware that textbooks and/or modules are produced with a general audience in the minds of material writers. They do not cater to individual needs or abilities of the learners. Thus, the adaptation to either enhance or simplify teaching and learning materials lies with the teacher. Furthermore, the teacher knows his/her teaching and learning context best. The onus to facilitate or even debilitate learning lies with the teacher.

I was assigned to facilitate the TSL3111 Developing and Using Resources for the Primary ESL Classroom subject this semester. Once again, I re-introduced this technique for material development. I had the opportunity to gauge their perception of the effectiveness of this technique using a simple in-use evaluation instrument adapted from Ellis (1998: 
235). During the Pameran Inovasi IPGKTAR 2013, I also gauged the perception of the effectiveness of these learning materials by student teachers who visited my exhibition booth. Below is a summary of their perception.

Evaluation of English language teaching and learning materials

\begin{tabular}{|c|c|c|c|}
\hline Item & Description & Respondents & Percent \\
\hline \multirow[t]{4}{*}{1} & How easily could you do the task? & 31 & \\
\hline & Very easily & 3 & 9.7 \\
\hline & Quite easily & 20 & 64.5 \\
\hline & Only with difficulty & 8 & 25.8 \\
\hline \multirow[t]{4}{*}{2} & How enjoyable did you find the tasks? & 31 & \\
\hline & Very enjoyable & 9 & 29.0 \\
\hline & Quite enjoyable & 19 & 61.3 \\
\hline & Not enjoyable & 3 & 9.7 \\
\hline \multirow[t]{4}{*}{3} & How much did this task help you to learn English? & 31 & \\
\hline & Very much & 18 & 58.1 \\
\hline & Some & 12 & 38.7 \\
\hline & Not very much & 1 & 3.2 \\
\hline
\end{tabular}

$4 \quad$ What did you LIKE about the task?

- The group work

- Information transfer activity; information-gap

- The speaking and sharing part

- Filling blanks with the initial letter given (2)

- The article about the tiger; the material's content (authentic)

- Pictures

- Reading for information

- The model (3)

- The instructions (4)

- Filling in the blanks

- Thinking of information outside the text.

5 What did you NOT LIKE about the task?

- The structure / the difficulties of the first question / the scientific terminology (2)

- The material's language style

- The language level

- The instruction (4)

- The model (2)

- Filling in the blanks

- Information in the reading text is not enough to answer all the aspects asked in the chart / Fill in information that is not in the article

- The information chart

- Too little information / insufficient information

- The layout

- The text

- There are no pictures on the paper.

- I don't like the wordy table.

\section{Findings}

Krashen's Comprehensible In-put hypothesis is addressed by the materials as only 3 or 9.7 percent of the respondents found the task very easy. A total of 28 or 90.3 percent experienced some difficulty in performing the task. It is agreed that tasks need to be challenging to motivate learners in their pursuit. On the other hand, they should also be not too easy as this could be demotivating.

A new component of the KSSR curriculum in relation to ELT is the introduction of Language Arts. Its rationale is to get learners to things with the language they had learned through the language skills components and to have fun while doing so. In other words, EL teachers are expected to make learning the language fun. These materials reveal that 28 or 
90.3 percent of the respondents did enjoy the tasks. Krashen's Affective Filter hypothesis is addressed by the design of these materials.

Having fun does not equal learning some times. However, 30 or 96.6 percent of the respondents believe that these tasks did help them learn the English language. This addresses the aim of the EL curriculum.

In view of liking or disliking the tasks, three respondents state that they dislike 'too little information', 'information in the text is not enough to answer all aspects asked in the chart', 'fill in information that is not in the article' while one respondent likes the 'thinking of information outside the text' element of the tasks. This is a crucial observation if we are serious in wanting to promote thinking outside the box, if I may. If the education system wants to produce a thinking people, rakyat with liquid intelligence, not rigid thinkers, then it starts with materials that promote thinking as opposed to the textbook I experienced as a learner and a teacher.

'There are no pictures on the paper (task sheet)' mourns one respondent. It can be interpreted that this is a visual learner. Again, the materials are revealing factors that are important considerations, such as multiple intelligence and learning styles, for material development. As the sample is negligible, these findings cannot be generalised.

\section{Conclusion}

A beginning teacher would likely rely upon the textbook or module as a source to wedge his/her teaching and learning process. The material in these sources being 'one size fits all' type is unlikely to meet the needs of a mixed-ability classroom. Teachers must be creative and innovative in the implementation of their lessons. Above all these, their materials must be effective and engaging. In this respect, Vygotsky believes that "properly organized learning" results in the mental development of children and sets "in motion a variety of developmental processes that would be impossible apart from learning" (1978: 90).

In a typical school, teachers are laden with preparation for up to 3 subjects. An EL teacher might be required to teach Mathematics and Physical Education beside English and Language Arts. On top of these, s/he needs to meet the mixedability nature of his/her classroom. Faced with the task to cater to this reality, it is a daunting responsibility for a beginning English Language (EL) teacher. This 'One text, multi tasking' technique of materials development could help a beginning or even a dedicated EL teacher deal with these individual learning styles while fulfilling many components of the Malaysian pedagogy standards for English Language Teaching.

Furthermore, these materials lend themselves well for teaching using models such as the inquiry and discovery methods, constructivism as well as taking learning beyond the confines of the classroom which comes through the responses of those who have experienced these learning materials.

\section{Reference}

Ab. Majid bin Mohd. S. (2006). Integrated Curriculum for Primary Schools. English Year 5. Sekolah Kebangsaan textbook. Melaka: DBP

Bahagian Buku Teks, KPM. (2010) Sejarah Penubuhan Bahagian Buku Teks. http://www.moe.gov.my/bbt/bbt_profil_bbt.php Accessed 27 May 2013

McEldowney P.L. (1992). MD339: Grammar and Communication in Learning A. Unit 1 Communicative Purposes. Manchester University: CELSE

Nunan, D. (1999). Second Language Teaching and Learning. Boston, Massachusetts 02116: Heinle \& Heinle Publishers

Tomasello, M. (1992). First Verbs - A Case Study of Early Grammatical Development. Cambridge: CUP

Oxford Dictionary of English Grammar, The (1994). S. Chalker, \& E. Weiner (Eds.). London: Quality Paperbacks Direct

Vygotsky, L.S. (1978). Mind in society: The development of higher psychological functions. M. Cole, V. John-Steiner, S. Scribner, \& E. Souberman (Eds.); M. Cole \& M. Lopez-Morillas (Trans.). Cambridge, MA: Harvard University Press Widdowson, H.G. (2008). Teaching Language as Communication (20 ${ }^{\text {th }}$ Edition). Oxford: OUP 




Answer these questions.

- Have you been to a paddy field before?

- Do you know how paddy is grown?

- Do you know how paddy is processed to become rice?

\section{Let's read}

Aiman's uncle, Encik Ismail, owns a large piece of paddy field in Seberang Prai. The paddy landowners there form an association and manage their paddy fields together as one big estate. The Farmers' Association supplies the farmers with fertilisers, pesticides and machines.

The farmers use tractors to level and plough the land. The transplanter machines plant the paddy seedlings directly into the soil.

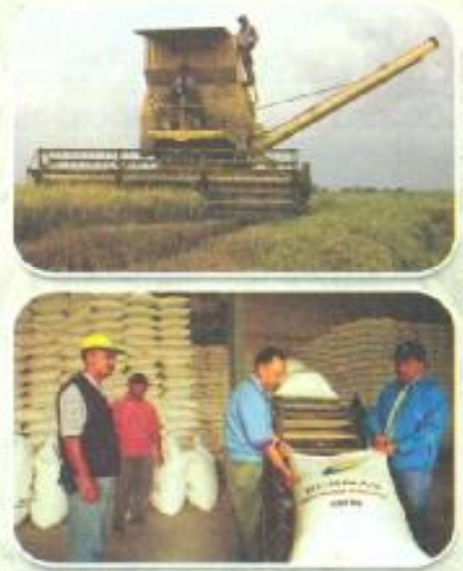

When the paddy is ready for
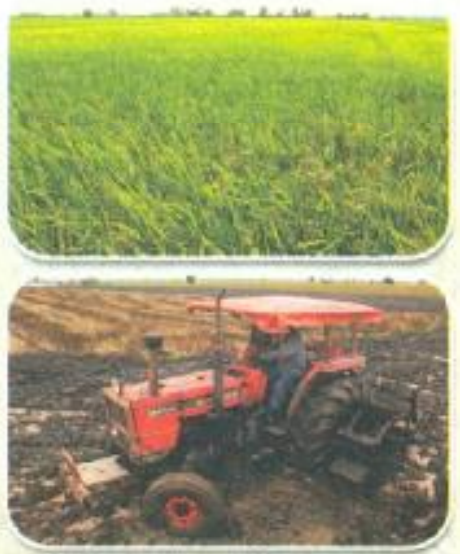
harvesting, the farmers use large combined harvesters. These machines harvest and thresh paddy in one operation.

At the rice mill the harvested paddy is processed into white rice. There are two basic steps in processing harvested paddy. Cleaning removes dirt and other impurities from the grains. After cleaning, a machine strips off both the husks and the bran until the grains become white rice.

In estate style farming, the paddy farmers are able to plant paddy systematically. This practice has improved rice production, thus increasing their income. 


\section{Answer the questions,}

(1. What does Encik Ismail own?
A. Farmers' Association
B. a large paddy field
C. the machines

2. Which is not true of estate style paddy farming?
A. Machines are upgraded.
C. Rice production is increased.
B. Farmers' income is raised.
D. Paddy is systematically planted.

3. All these are supplied by the association except ... .
A. paddy field
C. pesticides
B. fertilizers
D. machines

4. Explain how paddy is processed into rice at the rice mill.

5. How do machines help paddy farmers? Discuss.

6. Match the words in Column A to their meanings in Column B.

\begin{tabular}{|c|c|}
\hline Column A & Column B \\
\hline husk & furn over and cul furrows in the soil \\
\hline plough & substance added to soil or land to make it more fertile \\
\hline thresh & outer layer covering a grain \\
\hline fertilizers & substance used for destroying insects which are harmful to plants \\
\hline pesticides & separate grain from the stalks \\
\hline
\end{tabular}

\section{4., Let's dio}

\section{Group work}

The pictures show the farmers working in the paddy field.

Use all the words to describe the pictures.
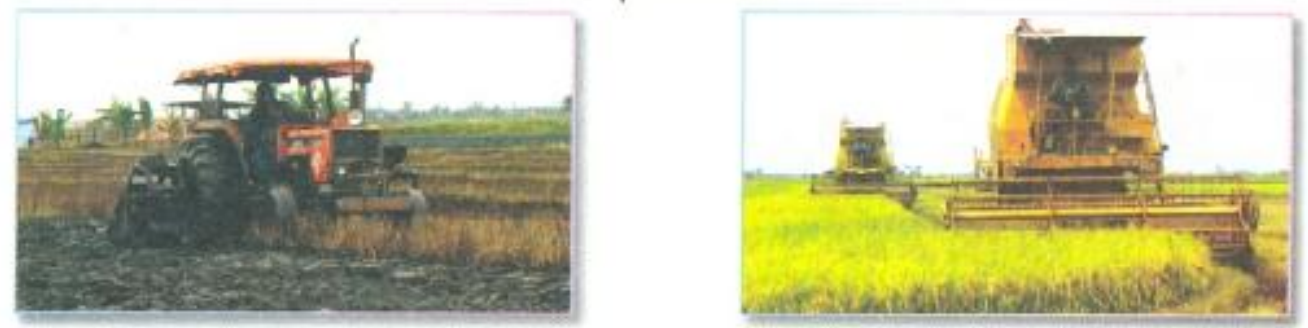

- prepares - land - planting

- paddy - ripe - harvest

- seeds - ploughs - tractor -

- harvesting machines - 


\section{Appendix 3}

\section{The core notes}

\begin{tabular}{|c|c|c|c|c|c|}
\hline What? & the process & Who/How? & Why? & What? & Where? \\
\hline tractors & are used & by farmers & $\begin{array}{l}\text { to level \& } \\
\text { plough }\end{array}$ & the land & - \\
\hline $\begin{array}{l}\text { paddy } \\
\text { seedlings }\end{array}$ & are & $\begin{array}{l}\text { by transplanter } \\
\text { machines } \\
\text { directly }\end{array}$ & - & - & into the soil \\
\hline ripen paddy & planted & $\begin{array}{l}\text { by combined } \\
\text { harvesters }\end{array}$ & - & - & $\begin{array}{l}\text { in one } \\
\text { operation }\end{array}$ \\
\hline $\begin{array}{l}\text { dirt \& other } \\
\text { impurities }\end{array}$ & is harvested & from the grains & - & - & $\begin{array}{l}\text { in two basic } \\
\text { steps }\end{array}$ \\
\hline $\begin{array}{l}\text { the husks \& } \\
\text { bran }\end{array}$ & $\begin{array}{c}\text { \& threshed } \\
\text { are removed } \\
\begin{array}{c}\text { are stripped } \\
\text { off }\end{array}\end{array}$ & by a machine & to produce & white rice & $\begin{array}{l}\text { at the rice } \\
\text { mill }\end{array}$ \\
\hline
\end{tabular}

- Use these notes to write a paragraph that describes the processes. The first sentence is done for you. The paragraph should be between $60-70$ words in length.

Tractors are used by farmers to level and plough the land. Paddy
seedlings are planted by transplanters directly into the soil. Ripen
paddy is harvested and threshed by combined harvesters in one
operation. Dirt and other impurities are removed from the grains in
two basic steps. The husks and bran are stripped off by a machine
to produce white rice at the rice mill.

64 words 


\section{Appendix 4}

\section{The task sheet}

- $\quad$ Read paragraph 2 - 4 quickly.

- Decide on a heading for the chart.

- Read the paragraphs again and fill the chart with information that describes the process.

- Think of information you would put in the shaded boxes.

Heading:

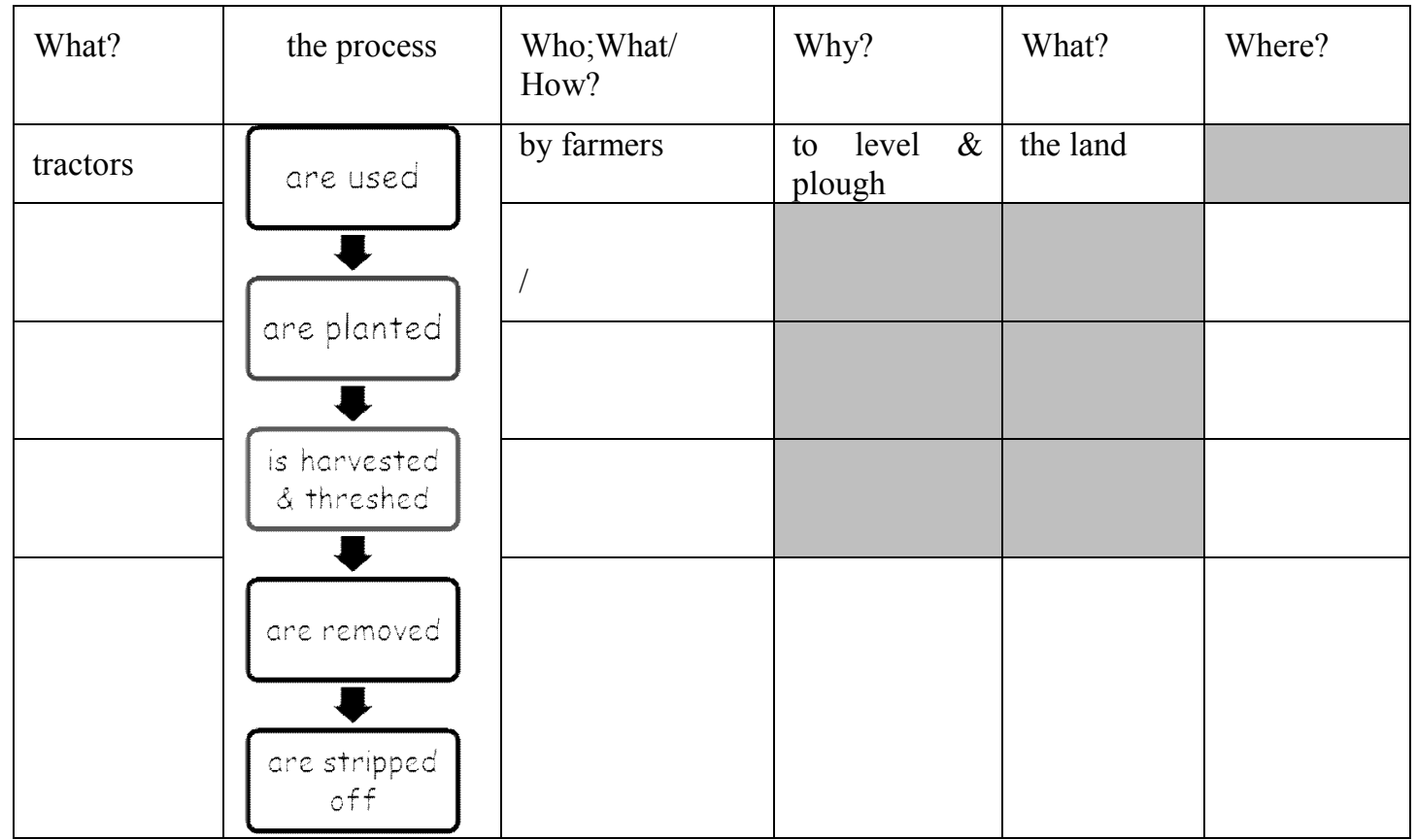

- Use these notes to write a paragraph that describes the processes. The first sentence is done for you. The paragraph should be between $60-70$ words in length.

Tractors are used by farmers to level and plough the land. 


\section{Appendix 5}

\section{The task sheet}

- $\quad$ Read paragraph 2 - 4 quickly.

- Decide on a heading for the chart.

- Read the paragraphs again and fill the chart with information that describes the process.

- No information might be needed in the shaded boxes.

Heading: Paddy planting and rice processing



Use the words/phrases below.

\begin{tabular}{|l|l|l|l|}
\hline by combined harvesters & in two basic steps & dirt \& other impurities & white rice \\
\hline by a machine & paddy seedlings & by farmers & paddy seedlings \\
\hline
\end{tabular}

\section{Appendix 6}

- Use these notes to write a paragraph that describes the processes. The first sentence is done for you. The paragraph should be between $60-70$ words in length.

Tractors are used by farmers to level and plough the land.
are planted by transplanter machines directly
one operation.
grains




\section{Appendix 7}

\section{The task sheet}

- $\quad$ Read paragraph 2 - 4 quickly.

- Decide on a heading for the chart.

- Read the paragraphs again and fill the chart with information that describes the process.

- No information is needed in the shaded boxes.

Heading: $\mathrm{P} \quad$ planting and rice pro



- Use these notes to write a paragraph that describes the processes. The first sentence is done for you. The paragraph should be between $60-70$ words in length.

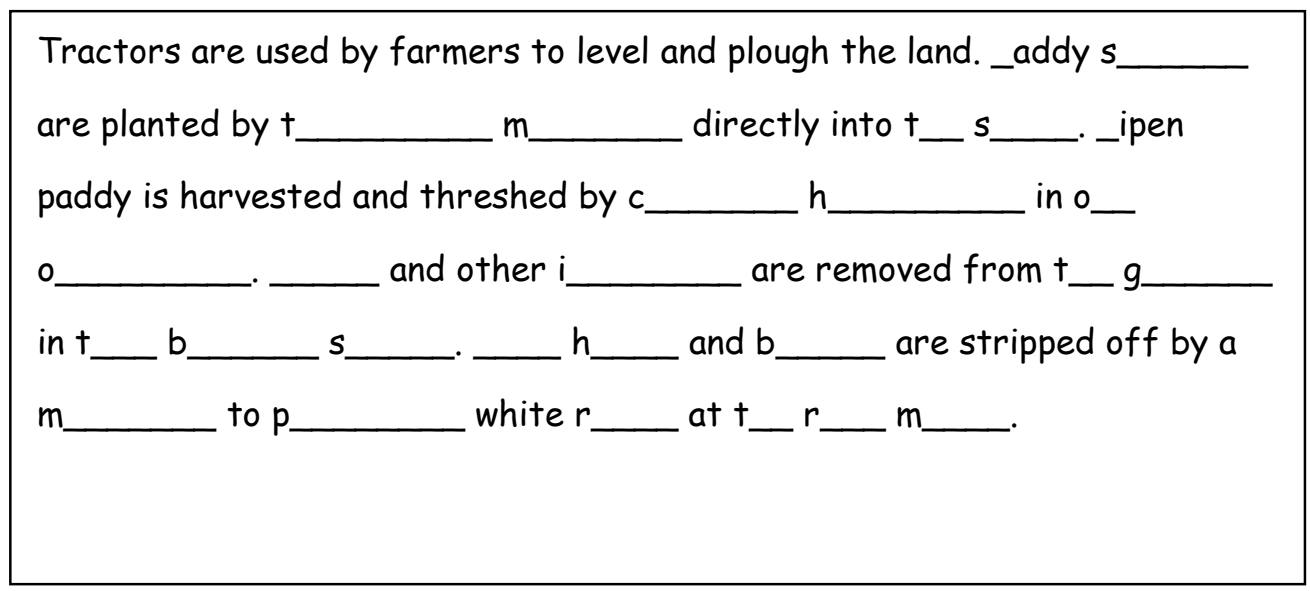

